\author{
УДК 343.1 \\ DOI 10.36511/2078-5356-2020-3-156-160
}

Алаев Руслан Сулейманович Ruslan S. Alaev

заместитель начальника

Управление экономической безопасности и противодействия коррупции Министерства внутренних дел по Чеченской Республике (364024, Чеченская Республика, Грозный, пр. Хусейна Исаева, 21)

deputy head

Directorate for economic security and combating the corruption of the Ministry of internal affairs for the Chechen Republic (21 Huseyn Isaev av., Grozny, Chechen Republic, Russian Federation, 364024)

E-mail: iren-nno@mail.ru

\author{
Освобождение от уголовной ответственности \\ в связи с полным возмещением ущерба от налогового преступления
}

\title{
Exemption from criminal liability in connection with full compensation for damage from a tax crime
}

Правовой механизм освобождения от уголовной ответственности в связи с возмещением ущерба в полном объеме становится основным средством противодействия налоговым преступлениям. Его дальнейшее развитие наталкивается на следственную фрорму досудебного производства по уголовным делам. Прежде всего, это проявляется в невозможности применения данного основания в стадии возбуждения уголовного дела, хотя это привело бы к значительному повышению эффективности данного правового механизма. Для того чтобы качественно изменить правовую систему противодействия преступлениям, связанным с нарушением налогового законодательства, необходимо реформировать институты обвинения и доказывания.

Ключевые слова: освобождение от уголовной ответственности, налоговые преступления, обвинение, доказывание, возмещение ущерба.
The legal mechanism for exemption from criminal liability in connection with compensation for damage in full is becoming the main means of countering tax crimes. Its further development runs into the investigative form of pre-trial proceedings in criminal cases. First of all, this is manifested in the impossibility of applying this basis at the stage of initiating a criminal case. Although this would lead to a significant increase in the effectiveness of this legal mechanism. In order to qualitatively change the legal system of combating crimes related to violation of tax legislation, it is necessary to reform the institutions of accusation and evidence.

Keywords: exemption from criminal liability, tax crimes, accusation, proof, compensation for damage.
Формирование компромиссно-штрафрной процедуры улаживания уголовно-правового спора между государством и налогоплательщиком (предпринимателем) стало одним из важнейших проявлений современной уголовной политики противодействия налоговой преступности. В этой процедуре вполне проявилась новая гуманная уголовно-правовая идеология, которая исходит из предположения о меньшей общественной опасности преступлений, совершаемых субъектами предпринимательской деятельности. Таким образом, уголовная ответственность этих субъектов может стать предметом соглашения между ними и государством в лице правоохранительных органов. Штрафрная санкция, материальная компенсация считаются оптимальными мерами правового воздействия на субъектов предпринимательской деятельности, нарушивших уголовный кодекс, по сравнению с наказанием, связанным с лишением свободы, которое применяется к остальным преступникам. Такова суть этой уголовно-

() Алаев Р.С., 2020 
правовой идеологии. Иными словами, вместо абстрактных ценностей вроде «объективной истины», «неотвратимости уголовной ответственности», «справедливости» предпочтение отдано достижению компромисса, целесообразности, фискальным интересам государства.

Реализуя данную уголовную политику противодействия налоговым и экономическим преступлениям в позитивном праве, законодатель в 2009 году Федеральным законом № 383-Ф3 [1] создал статью $28^{1}$ УПК РФ, которая первоначально специально была «заточена» под налоговые преступления. За прошедшие более чем десять лет изначальная процессуально-правовая модель шесть раз подвергалась модификациям и превратилась в общий уголовно-процессуальный механизм компромиссно-компенсаторного разрешения уголовно-правовых споров как между государством и субъектом предпринимательской деятельности (налогоплательщиком), так и между самими бизнесменами.

Анализируемый уголовно-правовой процессуальный механизм можно считать не столько новой особой формой реализации/применения уголовно-правовых норм, сколько проявлением партнерского, договорного способа разрешения уголовно-правовых конфликтов в сфере экономической и предпринимательской деятельности между государством и кругом лиц, в который входит около $1 \%$ населения России.

Известная в уголовно-процессуальной науке категория «диффреренциация уголовнопроцессуальной формы» в данном случае уже не вполне уместна для объяснения природы данного феномена, поскольку он уже не вполне вписывается в следственную форму, а уже перерастает за ее пределы. Речь идет о качественно новом уголовно-процессуальном явлении, в значительной мере проникнутом диспозитивным, исковым началами.

29 сентября 2020 года законопроект о внесении очередных изменений в редакцию статьи 281 УПК РФ [2] прошел третье чтение в Государственной Думе и был направлен в Совет Федерации. Можно не сомневаться, что седьмая редакция статьи $28^{1}$ УПК РФ до конца 2020 года станет частью уголовно-процессуальной системы противодействия налоговой преступности, равно как и преступности в сфере экономики. В результате отпадет имеющееся пока формальное ограничение (формулировка «до назначения судебного заседания» в части 1 статьи $28^{1}$ УПК РФ) на применение данного механизма в судебных стадиях. Таким образом, прекращение уголовного дела по данному ос- нованию будет возможным на любой стадии уголовного процесса. За исключением стадии возбуждения уголовного дела. Это и некоторые другие непреодолимые структурные ограничения на действие анализируемого правового механизма продолжат свое действие.

Можно констатировать, что на данном этапе правового развития законодателем задействован весь возможный потенциал следственной формы оптимизации анализируемого уголовно-процессуального механизма. Распространить его действие на ту же стадию возбуждения уголовного дела мешают типовые особенности следственной организации досудебного производства. Значит, следующий этап оптимизации рассматриваемой процедуры надо увязывать с более масштабными, институциональными изменениями в нашем уголовно-процессуальном праве.

В число этих институциональных основ современной уголовно-процессуальной системы входят обвинение и доказывание. Оба эти института имеют ключевое значение и в правовой организации процедуры прекращения уголовного дела по нереабилитирующему основанию.

Следственная форма не позволяет в полной мере реализовать идею договорного основания уголовной ответственности, диспозитивных прав сторон процессуального спора как о предмете уголовного иска (обвинения), так и средствах его доказывания, хотя теоретическую модель подобного правового механизма еще в XX веке предложил профессор А.С. Александров [3, с. 27-31].

Полагаем, что созданная А.С. Александровым процессуальная концепция диспозитивного уголовно-правового механизма может быть теоретико-методологической компонентой новой экономической уголовной политики, суть которой в переходе от репрессивного к компенсаторно-штрафному типу уголовно-правового воздействия; превалировании мотива целесообразности над неотвратимостью уголовной ответственности; переносе акцента в мере уголовной ответственности с личностного на компенсаторно-штрафной аспект.

Как уже отмечалось в уголовно-процессуальной литературе [4, с. $75-86 ; 5$, с. 94-98; 6, с. 136-143], в полной мере согласительнокомпенсаторный механизм разрешения уголовно-правовых конфрликтов между государством и субъектами предпринимательской деятельности, а тем более между самими субъектами предпринимательской деятельности может реализоваться только в состязательной уголовно- 
процессуальной среде, при диспозитивном методе правового урегулирования центрального уголовно-правового механизма.

Среди плодотворных идей, обсуждаемых в правоведении новейшего времени, является идея «сервисного государства», суть которой сведение роли государства к субъекту, оказывающему услуги населению и бизнесу — в сорере предпринимательской и иной деятельности [7, с. 9-12, 223]. Такое государство более склонно к компромиссу, чем государство, посредством наказания добивающееся наведения «социальной справедливости» (ст. 43 УК РФ).

Еще одной теоретико-методологической компонентой принципиально нового процессуального механизма разрешения уголовно-правовых споров могла бы быть концепция «процессуального детерминизма» [4, с. 75-86]. Создатели этой концепции, отрицая материальное происхождение основания уголовной ответственности, настаивают на том, что основание уголовной ответственности формируется в ходе процесса на доказательствах обвинения. «Преступление есть доказанное обвинение» или «нет преступления без обвинения» [4, с. 8586]. Данная концепция позволяет объяснить и оправдать то, что основание уголовной ответственности создается сторонами в ходе доказывания обвинения. Доказанное в суде обвинение есть основание уголовной ответственности, которая реализуется после вступления обвинительного приговора суда в законную силу. Будучи субъектами диспозитивности стороны в деле могут распоряжаться материальным правом на обвинение: со стороны обвинения это выражается как фрормулирование предмета обвинения и его выдвижение или отказ от обвинения. А со стороны защиты диспозитивные процессуальные полномочия выражаются в распоряжении правом на признание обвинения - полностью или частично [7, с. 121-126].

Принцип наибольшего благоприятствования при использовании основания для прекращения правовых отношений между государством и лицом, виновным в совершении налогового преступления, в отношении которого осуществлялось уголовное преследование, заключается в том, что правоприменитель при наличии выбора обязан использовать основание, порождающее наиболее благоприятные правовые последствия для лица, в отношении которого выносится процессуальное решение. Мы полагаем, что на нем зиждется разделение этих оснований по нескольким очередям. Основаниями первой очереди являются «общие», императивно-обя- зывающие основания прекращения уголовных дел. Основаниями второй очереди выступают основания, предусмотренные статьей 281 УПК РФ. И, наконец, в третью очередь входят основания, предусмотренные статьей $25^{1}$, пунктом 3 части 1 статьи 27, статьей 28 УПК РФ.

Роль прокуратуры в принятии на предварительном расследовании решения о прекращении уголовного дела о налоговом преступлении в соответствии со статьей $28^{1}$ УПК РФ должна быть решающей, поэтому заключать такое соглашение и затем утверждать решение следователя (а) об отказе в возбуждении уголовного дела или (б) о его прекращении должен прокурор, а руководитель следственного органа предварительно его согласовывать.

При сохранении существующего типа уголовного процесса для оптимизации процедуры прекращения уголовного дела в ходе досудебного производства предлагается дополнить его нормами, регулирующими: (1) предварительное соглашение сторон об условиях (а) возмещения ущерба, размере выплаты и (б) отказа от уголовного преследования - в стадии возбуждении уголовного дела или прекращения уголовного дела (преследования) - в стадии предварительного расследования; (2) порядок и содержание такого соглашения как в стадии возбуждения уголовного дела, так и в стадии предварительного расследования; (3) ограничение его заключение моментом: не позднее принятия итогового решения в стадии; (4) наделение прокурора полномочиями на (а) заключение соглашения со стороной защиты и (б) принятие решения об отказе в возбуждении уголовного дела или (в) прекращение возбужденного уголовного дела; (5) возможные условия соглашения, в том числе (а) о снятии ареста с имущества, ценных бумаг обвиняемого, (б) обязательства третьего лица возместить ущерб, (в) сумму, подлежащую уплате правообязанным лицом, (г) другие пункты, которые по усмотрению прокурора могут быть включены в условия прекращения уголовного преследования: ввиду повторности деяния, особо крупного размера ущерба и пр.

Можно констатировать, что на настоящий момент институт прекращения уголовных дел о налоговых преступлениях по нереабилитирующим диспозитивно-дискреционным основаниям, связанным с возмещением ущерба, является деталью правового механизма противодействия налоговой преступности и упорядочивания правоотношений между государством и налогоплательщиками. Его утилитарным назначением является возможно полное и быстрое 
возмещение причиненного налоговым преступлением ущерба. Конечной целью прекращения уголовных дел о налоговых преступлениях по основаниям, связанным с возмещение ущерба, является обеспечение экономической безопасности государства и его эффективности.

При этом правоприменителем решаются задачи: (1) принятие правомерного процессуального решения о прекращении уголовного дела, которым вместо наказания за доказанный факт совершения налогового преступления применяется альтернативная мера уголовно-правового воздействия; (2) достижение быстрого и полного возмещения установленного ущерба от налогового преступления; (3) устранение социальной опасности изобличенного в совершении налогового преступления обвиняемого; (4) экономия сил и средств правоохранительной системы по выявлению и раскрытию налоговых преступлений за счет упрощения расследования или судебного рассмотрения уголовного дела.

Особенностями прекращения уголовных дел о налоговых преступлениях в судебных стадиях являются, во-первых, специфический набор оснований и особенности их применения в отдельных стадиях; во-вторых, принятие решения о прекращении уголовного дела (преследования) судом в условиях состязательной судебной процедуры, что делает его актом правосудия (хотя в полной мере - в стадии судебного развбирательства); в-третьих, доминантой судебной процедуры является позиция прокурора - государственного обвинителя: его отказ от поддержания обвинения ведет к прекращению уголовного дела; в-четвертых, прекращение уголовного дела (преследования) по нереабитирующим основаниям, в связи с возмещением ущерба, а также по основаниям, предусмотренным пунктами 3-4 статьи 24 УПК РФ, возможно только с согласия обвиняемого/ подсудимого.

В связи с этим предлагается внести в статьи 239 и 254 УПК РФ норму о том, что прекращение в судебных стадиях уголовного дела по основаниям, предусмотренным пунктами 3-4 статьи 24, пунктами 3 статей $27,28,28{ }^{1}$ УПК РФ, а также в случае принятия уголовного закона, исключающего преступность деяния, то есть по пункту 2 статьи 24 УПК РФ, возможно только с согласия обвиняемого, подсудимого (или его родственников - в случае смерти обвиняемого). В отсутствие такого согласия, в том числе и при отказе прокурора поддерживать обвинение, суд обязан рассмотреть дело по существу и вы- нести приговор, оправдательный или обвинительный, но без назначения наказания [8].

Эти и другие предложения направлены на модификацию копромиссно-компенсаторного механизма разрешения уголовно-правовых споров, предметом которых является налоговое преступление, в современной уголовно-процессуальной системе.

В целом же мы выступаем за то, чтобы в налоговой сфере уголовно-правовые конфликты урегулировались на диспозитивной процессуальной основе. Состязательно-обвинительная процессуально-правовая основа привлечения к уголовной ответственности включает в себя и процедуру досудебного урегулирования спора, когда представитель обвинительной власти (прокурор) предлагает лицу, изобличенному собранным полицией доказательственным материалом в совершении преступления, под угрозой предъявления обвинения и последующего наказания, загладить причиненный преступлением вред, совершить другие действия по улаживанию конфликта. Здесь субъект права на уголовный иск (обвинение) распоряжаться этим правом в фрорме отказа. Однако для реализации подобной модели требуются масштабные, структурные изменения всей уголовно-процессуальной системы и в первую очередь - peформа предварительного расследования.

\section{Примечания}

1. О внесении изменений в часть первую Налогового кодекса Российской Федерации и отдельные законодательные акты Российской Федерации: федеральный закон от 29 декабря 2009 № 383-Ф3 (ред. от 07.02.2011) // Собрание законодательства РФ. 2010. № 1 , ст. 4.

2. Законопроект № 863715-7 «О внесении изменения в статью 28-1 Уголовно-процессуального кодекса Российской Федерации (об уточнении порядка прекращения уголовного преследования в связи с возмещением ущерба, причиненного бюджетной системе Российской Федерации)». URL: https://sozd.duma.gov. ru/bill/863715-7 (дата обращения: 30 сентября 2020).

3. Александров А.С. Диспозитивность в уголовном процессе. Н. Новгород: НЮИ МВД РФ, 1997. 209 с.

4. Александров А.С., Александрова И.А., Власова С.В. Теоретическая концепция государственно-правовой организации противодействия преступности в 21 веке // Государство и право. 2019. № 9. С. 75-86.

5. Александрова И.А., Алаев Р.С. Правовой институт прекращения уголовного преследования в связи с возмещением ущерба: вопросы теории и практики // Российский правовой журнал. 2019. № 1. С. 94-98.

6. Шерстнев В.Б. Прекращение уголовного преследования в связи с полным возмещением ущер- 
ба // Вестник Санкт-Петербургского университета МВД России. 2020. № 1. С. 136-143.

7. Власова С.В. Теоретическая концепция правовой (уголовно-процессуальной) организации противодействия преступности в сфере экономики: монография. М.: Юрлитинформ, 2020. 440 с.

8. По делу о проверке конституционности части первой статьи 10 Уголовного кодекса Российской Федерации, части второй статьи 24, части второй статьи 27, части первой статьи 239 и пункта 1 статьи 254 Уголовно-процессуального кодекса Российской Федерации в связи с жалобой гражданки А.И. Тихомоловой: постановление Конституционного Суда РФ от 15 октября 2018 г. № 36-П // Собрание законодательства РФ. 2018. № 44, ст. 6821.

\section{References}

1. On amendments to part one of the Tax Code of the Russian Federation and certain legislative acts of the Russian Federation: federal law of December 29, 2009 no. 383-FZ (as amended on February 7, 2011). Collection of legislative acts of the RF, 2010, no. 1, art. 4 . (In Russ.)

2. Bill no. 863715-7 "On Amending Article 28-1 of the Criminal procedure code of the Russian Federation (on clarifying the procedure for terminating criminal prosecution in connection with compensation for damage caused to the budgetary system of the Russian Federation)". URL: https://sozd.duma.gov.ru/bill/863715-7 (accessed 30.09.2020). (In Russ.)
3. Aleksandrov A.S. Dispositiveness in the criminal process. Nizhny Novgorod: NYU of the Ministry of Internal Affairs of the Russian Federation, 1997. 209 p. (In Russ.)

4. Aleksandrov A.S., Aleksandrova I.A., Vlasova S.V. Theoretical concept of state-legal organization of combating crime in the 21st century. State and law, 2019, no. 9, pp. 75-86. (In Russ.)

5. Alexandrova I.A., Alaev R.S. Legal institute of termination of criminal prosecution in connection with compensation for damage: theory and practice. Russian legal journal, 2019, no. 1, pp. 94-98. (In Russ.)

6. Sherstnev V.B Termination of criminal prosecution in connection with full compensation for damage. Bulletin of the St. Petersburg University of the Ministry of Internal Affairs of Russia, 2020, no. 1, pp. 136-143. (In Russ.)

7. Vlasova S.V. Theoretical concept of legal (criminal procedural) organization of combating crime in the economic sphere: monograph. Moscow: Jurlitinform Publ., 2020. 440 p. (In Russ.)

8. In the case of checking the constitutionality of part one of Article 10 of the Criminal Code of the Russian Federation, part two of article 24, part two of Article 27, part one of article 239 and paragraph 1 of article 254 Criminal of the procedural code of the Russian Federation in connection with the complaint of citizen A.I. Tikhomolova: resolution of the Constitutional Court of the Russian Federation of 15.10 .2018 no. 36-P. Collection of legislative acts of the RF, 2018, no. 44, art. 6821 . (In Russ.) 